\title{
Urgensi tabayyun dan kualitas informasi dalam membangun komunikasi
}

\author{
Faisal Syarifudin \\ UIN Sunan Kalijaga Yogyakarta \\ e-mail: faisal.syarifudin@uin-suka.ac.id
}

\begin{abstract}
This paper aims to show the urgency of tabayyun in establishing good communication and its theoretical implication. The empirical occasion in which al-Hujurat: 6 was revealed has a great relevance to the situation in the modern day where many problems result from the dissemination of information. The study of literatures demonstrates that several criteria of information quality extracted from al-Qur'an and modern theories complement each other to build a theoretical model that involves the characteristics of iman and fasiq in the personality of communicators and communicants.
\end{abstract}

Keywords: tabayyun, communication, iman, fasiq, theoretical implication

\begin{abstract}
ABSTRAK
Tulisan ini bertujuan untuk menunjukkan urgensi tabayyun dalam membangun komunikasi beserta implikasi teoretisnya. Urgensi tabayyun sangat jelas pada kasus yang menjadi latar belakang turunnya ayat keenam surah al-Hujurat yang semakin relevan di dalam kehidupan modern di mana penyebaran informasi melahirkan banyak problem. Penelitian literatur ini menunjukkan beberapa kriteria kualitas informasi yang digali dari al-Qur'an dan teori modern yang saling melengkapi untuk membangun model teoretis komunikasi yang melibatkan karakter iman dan fasiq pada diri komunikator dan komunikan.
\end{abstract}

Kata Kunci: tabayyun, komunikasi, iman, fasiq, implikasi teoretis

\section{A. PENDAHULUAN}

Tulisan ini berupaya menghubungkan konsep tabayyun yang dilahirkan oleh kitab suci al-Qur'an berbasiskan peristiwa empiris di masa Nabi Muhmmad dengan konsep kualitas informasi yang tujuannya adalah membangun komunikasi efektif. Penulis mengambil model komunikasi paling sederhana dengan tiga unsur yaitu pengirim pesan, pesan yang disampaikan, dan penerima pesan. Sebagaimana akan terlihat pada bagian berikutnya, ayat tentang tabayyun memuat ketiga unsur utama dari model komunikasi sederhana itu, yang bangunannya kemudian dilengkapi unsur-unsur kualitas informasi.

Tabayyun yang berasal dari ranah keagamaan penting diposisikan menjadi konsep dalam bidang komunikasi untuk diuji keterhubungannya dengan teori yang berlaku, sehingga kebenarannya tidak diklaim secara apriori. Komunikasi juga bersentuhan dengan problem etis, maka konsep tabayyun ini menjadi satu landasan etika dalam berkomunikasi. Dengan latar belakang ini penulis mencoba melihat bagaimana urgensi tabayyun dan bagaimana implikasi teoretisnya yang menekankan pada informasi berkualitas sebagai distingsi iman dan fasiq di dalam diri komunikator penyampai pesan. Karya ini berkontribusi secara teoretis pada model komunikasi dengan memasukkan karakteristik komunikator dan komunikan sebagai pelaku kegiatan komunikasi. 


\section{B. TINJAUAN PUSTAKA}

Bagian awal dari tinjauan pustaka ini mengajukan beberapa literatur terkait. Ada empat buah karya terdahulu dengan topik tabayyun yang relevan untuk disebutkan di sini. Erwan Efendi (2016) menulis artikel "Tabayyun dalam Jurnalistik," di dalamnya ia menegaskan konsep tabayyun sangat melekat dengan profesi wartawan yang wajib melakukan check and recheck sehingga pemberitaan menjadi berimbang dan proporsional. Ghazali dkk. (2017) dalam artikel mereka "To Share or Not to Share: Tabayyun Made Possible with MyVeri5" menyoroti penyalahgunaan media sosial untuk menyebarkan desas desus, yang dari sisi teknologi, hampir tidak ada bantuan sama sekali dalam memverifikasi keaslian pesan yang dibagikan. Pengguna harus berusaha keras untuk memverifikasi berita. Ghazali dkk. melalui aplikasi seluler bernama MyVeri5 berupaya mewujudkan tabayyun untuk memverifikasi keaslian pesan sebelum pengguna menyebarkannya kepada orang lain.

Karya Arifin (2018) berjudul "Kajian Komunikasi Massa pada Surah Al-Hujurat Ayat 6" berupaya mengintegrasikan teori komunikasi massa dengan nilai-nilai pada surah Alhujurat ayat 6 , di bawah semangat kontekstualisasi ajaran Islam terhadap perkembangan zaman. Artikel ini menyimpulkan konsep tabayyun berisi kehati-hatian dan ketelitian dalam menyikapi informasi maupun media penyampai infomasinya. Muhammad Usman Noor (2018) menulis "Penilaian Kualitas Informasi sebagai Bentuk Sikap Tabayyun ketika Menerima Informasi di Sosial Media dan Internet." Noor menautkan urgensi tabayyun dengan metode penilaian informasi yang berkualitas melalui tiga aspek utama, yaitu reputasi penanggung jawab isi informasi, relevansi isi informasi, dan representasi informasi.

Literatur di atas menjalin konsep tabayyun dalam kerangka kajian informasi dan komunikasi, demikian pula artikel ini. Keseluruhannya menunjukkan selarasnya terminologi dari ranah keagamaan dengan teori informasi dan komunikasi modern. Artikel penulis ini mendukung pandangan tersebut dan memperkaya melalui suatu teorisasi model komunikasi.

Selanjutnya dikemukakan kajian teori yang mendukung argumen penulis, dimulai dengan pengertian dan unsur komunikasi. Vardiansyah memberikan definisi sederhana bahwa komunikasi adalah penyampaian pesan antar manusia (Vardiansyah 2004, 9). Sedangkan Hefni mengemukakan bahwa komunikasi adalah proses berbagi dan membagi pengalaman dengan tujuan saling mempengaruhi (2015, 9). Pengertian ini menyatakan bahwa komunikasi adalah sebuah proses dengan adanya unsur-unsur pengirim pesan (komunikator), pesan yang dikirimkan dan penerima pesan (komunikan), dalam satu arah ataupun timbal balik. Itulah tiga unsur utamanya, yang merupakan unsur minimal (Soyomukti 2016, 58). Unsur lain yang sering dimasukkan adalah saluran, media komunikasi dan efek komunikasi. Dengan tiga unsur dasar komunikasi tersebut penulis mencoba menggambarkannya dalam model sederhana berikut:

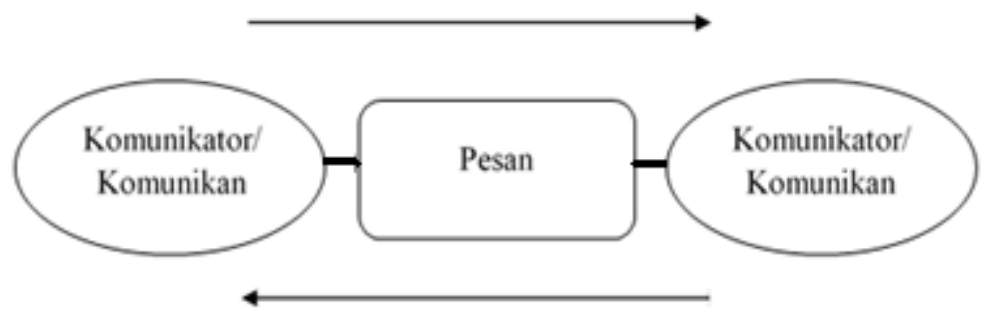

Gambar 1. Model komunikasi dengan tiga unsur minimalnya

Model ini menunjukkan bahwa komunikasi bisa berjalan satu arah saja, yang penerima pesannya tidak bertindak aktif mengirimkan pesan. Tetapi pada umumnya terjadi komunikasi timbal balik, maka saat itu penerima juga menjadi pengirim pesan dan 
sebaliknya. Terdapat banyak model yang melibatkan sumber, destinasi, media, kode, efek dan gangguan dalam komunikasi. Pembaca dapat temukan di dalam buku-buku khusus bidang ini. Setidaknya model sederhana di atas akan berguna bagi penjelasan teoretis mengenai peranan tabayyun dalam membangun komunikasi dalam berbagai fungsinya.

Komunikasi merupakan tindakan yang tidak bisa dipisahkan dari kehidupan manusia karena ia terus menerus menyampaikan dan menerima pesan. Untuk itu komunikasi berdasarkan fungsinya bisa dikelompokkan menjadi: komunikasi sosial, komunikasi ekspresif, komunikasi ritual, dan komunikasi instrumental, sebagaimana dimuat dalam karya Dedy Mulyana Ilmu Komunikasi Suatu Pengantar (Mulyana 2012). Secara singkat penjelasannya sebagai berikut.

Fungsi pertama komunikasi sosial, dilakukan karena manusia berada di dalam suatu lingkungan sosial di mana penting baginya untuk membangun konsep diri, aktualisasi diri, untuk kelangsungan hidup, memperoleh kebahagiaan, menghindari stres lewat komunikasi yang menghibur. Contoh fungsi ini adalah orang yang berpidato di dalam rapat, dan saling saling menyapa dengan tetangga sehingga hubungan menjadi akrab (hal. 6). Fungsi kedua, komunikasi ekspresif dilakukan sebagai alat untuk menyampaikan perasaan, misalnya ucapan selamat kepada teman yang menikah, demonstrasi oleh mahasiswa di kampus (hal. 24).

Fungsi ketiga komunikasi ritual, biasanya dilakukan di dalam kegiatan bersama yang menjadi ritus-ritus di dalam hidup manusia atau rites of passage (hal. 27). Ketika seorang bayi dilahirkan diadakan upacara pemberian nama, dibacakan doa, ketika sunatan juga dibacakan doa. Saat ulang tahun ada ucapan selamat dan nyanyian. Seterusnya dapat ditemui orang mengucapkan kata-kata dan berperilaku simbolik dalam lamaran, pernikahan, dan dalam ritual ibadah keagamaan.

Fungsi keempat komunikasi instrumental, dilakukan untuk menginformasikan, mengajar, mendorong, dan mengubah sikap dan keyakinan (hal. 33). Misalnya pesan-pesan yang disampaikan oleh guru dan dosen di kelas agar tertanam pengetahuan atau perilaku yang baik. Oleh politisi agar mendapatkan suara dalam pemilihan, atau oleh penceramah agama untuk membina moral dan meningkatkan keimanan. Keempat fungsi komunikasi ini tidak dapat dipisahkan secara kaku, karena dalam suatu tindakan dapat berlaku lebih dari satu fungsi komunikasi dengan bersamaan.

Pesan merupakan informasi yang dikomunikasikan. Agar fungsi komunikasi yang telah disebutkan dapat tercapai, pesan yang disampaikan harus berkualitas. Para peneliti di dalam berbagai bidang menekankan pentingnya informasi berkualitas. Misalnya Azemi, Zaidi, dan Hussin (2018) menyebut kualitas informasi merupakan aspek yang sangat penting di dalam manajemen. Pada penelitian kepuasan pelanggan bisnis, Kenett dan Salini (2011) menyatakan kualitas informasi sebagai suatu potensi dari rangkaian data untuk mencapai tujuan spesifik. Bagi Gorla, Somers dan Wong (2010) yang dalam riset mereka membangun model relasi antara sistem informasi dan dampaknya terhadap organisasi, kualitas informasi adalah sebuah konsep yang dapat dijelaskan sebagai output yang berguna bagi pengguna bisnis, yang relevan untuk pengambilan keputusan, mudah dipahami serta sebagai output yang memenuhi spesifikasi informasi pengguna. Salah satu contoh pentingnya kualitas informasi adalah penelitian Marang-van de Mheen dkk. (2011) yang menyimpulkan bahwa pasien yang hendak menggunakan jasa rumah sakit di Belanda mementingkan informasi mengenai perawatan dan mutunya, sebelum menentukan ke mana pasien pergi untuk layanan bedah. Kenyataannya memang di dalam keseharian, informasi yang baik atau buruk memengaruhi hubungan antar pribadi, pergaulan sosial, kepentingan bisnis hingga kehidupan berbangsa.

Kualitas informasi ditentukan melalui tiga dimensi, yaitu waktu, isi, dan bentuknya. Dimensi waktu informasi mencakup ketepatan (timeliness); informasi pada waktu yang tepat 
ketika diperlukan., selanjutnya informasi harus mengandung kebaruan (currency); informasi terkini, up to date yang sering diperlukan sebagai bahan evaluasi atau prediksi waktu masa ke depan. Dimensi isi adalah penyajian informasi itu secara detail sampai pada tingkat yang tepat atau berupa ringkasan saja yang keduanya sama-sama dibutuhkan oleh pemakai dalam level yang berbeda meskipun di dalam organisasi yang sama. Sedangkan dimensi bentuk mencakup informasi yang disajikan misalnya berupa narasi, gambar, audio atau bahkan video (Humdiana dan Indrayani 2006, 20). Meskipun demikian tidaklah cukup hanya mempertimbangkan atau membatasinya pada tiga dimensi tersebut semata, sebab dengan adanya perangkat komunikasi yang canggih muncul semakin luas masalah sosial dan hukum dari penggunaan informasi.

\section{METODE}

Penulis mengumpulkan data berupa istilah-istilah dan penjelasannya dari sumbersumber yang telah tersedia di dalam literatur, yaitu kitab tafsir, artikel-artikel yang membahas tabayyun, kamus, dan buku-buku yang membahas informasi dan komunikasi dan topik-topik yang relevan. Karya semacam ini menurut Mestika Zed merupakan riset pustaka atau penelitian kepustakaan $(2004,4)$, yaitu peneliti berhadapan dengan teks atau nash. Kemudian penulis melakukan analisis tematik dengan melihat hubungan antar konsep, dan menarik kesimpulan secara induktif (Dawson 2002, 115). Pembahasan dimulai dengan turunnya ayat tentang tabayyun, diikuti uraian mengenai urgensi tabayyun dan kualitas informasi. Kemudian penulis mencoba melihat implikasi teoritisnya dalam bidang komunikasi.

\section{HASIL DAN PEMBAHASAN \\ Setting QS al-Hujurat: 6}

Ayat ini turun menyangkut laporan dari utusan Nabi saw. dalam urusan pengumpulan zakat. A.A. Dahlan dkk. $(2000,513)$ mencatat asababun nuzul dengan menyebut riwayat bahwa Nabi Muhammad saw. mengislamkan seorang laki-laki bernama al-Harits dan menyuruhnya mengeluarkan zakat. Laki-laki ini menyanggupi, bahkan mengajak kaumnya berislam dan mengeluarkan zakat pula. Ketika zakat mereka telah banyak terkumpul, mereka menunggu utusan Nabi yang datang mengambil zakat, namun tidak seorang pun yang datang. Akhirnya al-Harits dan kaumnya yang telah berislam berangkat menghadap Nabi.

Nabi Muhammad, sesuai waktu yang ditetapkan mengutus al-Walid bin Uqbah untuk mengambil zakat tersebut. al-Walid merasa gentar dan kembali sebelum menyelesaikan tugasnya, dan memberi laporan palsu bahwa mereka akan menyerangnya. Nabi mengirim utusan kedua, yang akhirnya bertemu dengan kaum al-Harits. Mereka sampai di hadapan Nabi dan beliau bertanya: "mengapa engkau menahan zakat dan akan membunuh utusanku?" Al-Harits menjawab: "Demi Allah yang mengutus engkau, aku tidak berbuat demikian." Kemudian turunlah ayat ini yang memerintahkan agar orang beriman bertabayyun, mengklarifikasi terlebih dahulu ketika menerima informasi sehingga tidak terjadi penyesalan akibat salah menjatuhkan hukuman.

Tafsir al-Thabari (2009, Jil. 23:715-22) mencantumkan sembilan riwayat dari Nabi saw. yang semuanya memperkuat sebab turunnya ayat di atas. Disebutkan bahwa al-Harits berasal dari Bani Mushtaliq, dan ayat ini berkaitan dengan utusan bernama Walid bin Uqbah yang dikirim Nabi saw. untuk mengumpulkan zakat mereka. Selain itu ada keterangan bahwa pembacaan ahli Qiraat Madinah untuk (fataśabbatū). Keduanya adalah qiraat yang dikenal dan maknanya tidak jauh berbeda, dan keduanya diangggap benar. 
Turunnya perintah tabayyun mencegah orang-orang yang beriman saling berperang akibat informasi tidak akurat yang dibawa oleh seorang fasiq. Apabila dikaitkan dengan komunikasi, maka tabayyun, memeriksa informasi dengan teliti adalah sikap yang relevan dalam setiap kondisi masyarakat.

\section{Urgensi Tabayyun dan kualitas informasi}

Pada masa turunnya ayat tabayyun, penyampaian berita masih memakan waktu lama karena belum ada teknologi komunikasi, sehingga informasi bisa simpang siur. Pesan yang disampaikan hanya terekam di dalam memori manusia, dan ketika diteruskan kepada orang berikutnya sangat mungkin terjadi pengurangan, penambahan, bahkan distorsi. Masalah ini bisa diatasi setelah munculnya budaya tulis di masyarakat. Tulisan menyimpan informasi dengan lebih baik dibandingkan ingatan di kepala manusia serta bertahan lebih lama, walaupun tetap saja dapat terjadi kesalahan dalam membacanya dan memberi makna. Di masa modern komunikasi berlangsung sangat cepat dan masif secara lisan dan tertulis mengandalkan berbagai perangkat canggih. Akan tetapi di masa modern ini kesimpangsiuran informasi semakin marak terjadi akibat mudahnya orang menyampaikan berita melalui berbagai media. Saluran informasi dikuasai secara personal karena setiap pemilik perangkatnya bisa mengunggah tulisan, gambar dan rekaman, dengan tujuan baik atau tujuan buruk. Tersebarlah berita-berita tanpa terkecuali yang palsu. Maka sangat urgen untuk menyikapinya dengan hati-hati dan teliti.

Tabayyun berasal dari kata tabayyana تبيّن yang berarti menjadi jelas (Kamus Online Almaany, 2019). Tabayyun didefinisikan sebagai mengedepankan klarifikasi, mencari hakikat berita dan memeriksa seluk beluknya (Hanafi 2017). Sumber utama harus jelas, dan beberapa sumber saling mendukung. Orang yang menerima informasi dapat bersikap adil setelah melakukan tabayyun (Kahfi 2006).

Di dalam komunikasi, seperti telah disinggung sebelumnya bisa ditemukan minimal tiga unsur: komunikator, pesan, dan komunikan. Unsur-unsur itu terlihat dengan jelas di dalam QS al-Hujurat: 6. Pihak yang dihimbau oleh ayat tersebut adalah orang-orang yang beriman dalam posisi mereka sebagai komunikan atau penerima pesan. Orang fasiq posisinya sebagai komunikator, pembawa pesan, dan berita atau laporan yang disampaikannya merupakan pesan dalam komunikasi. Sebagai orang yang beriman, komunikasi difungsikan supaya keadilan dapat ditegakkan setelah terlebih dahulu ada kejelasan dalam pesan yang disampaikan, serta meneliti motif dari siapa yang menyampaikannya. Pertikaian yang tidak perlu, sampai pertumpahan darah terjadi jika di dalam konteks masa Nabi itu beliau langsung mempercayai perkataan utusannya. Padahal utusan tersebut telah melalaikan tugas karena merasa gentar, tetapi untuk menjaga kredibilitas dikatakannya bahwa sekelompok orang yang baru masuk Islam itu menolak menyerahkan zakat. Dalam masalah tersebut, Nabi tentu berpegang kepada perjanjian tentang kesediaan mereka berzakat, maka wajarlah apabila beliau marah. Ayat bersifat yang imperatif ini menjadi kesempatan untuk mengklarifikasi kebenaran sebuah laporan, dan caranya adalah mengirimkan utusan berikutnya hingga kedua belah pihak sampai di hadapan Nabi.

Tabayyun menghasilkan informasi yang berkualitas dan menghindarkan diambilnya keputusan yang salah. Karakteristik informasi berkualitas diidentikasi oleh banyak peneliti, yang dirangkum oleh Widarsono (2007) sebagai berikut,

1. Relevant: dapat mengurangi ketidakpastian,

2. Reliable: terpercaya apabila dia bebas dari kesalahan dan bias, serta akurat, 
3. Complete: sempurna, bila dia tidak meninggalkan aspek-aspek penting yang melatarbelakangi suatu kejadian atau aktivitas yang diukur,

4. Timely: tepat waktu bila informasi tersedia pada waktu para pengambil keputusan menggunakannya untuk membuat keputusan,

5. Understandable: bila disajikan dalam format yang berguna dan dapat dimengerti,

6. Verifiable: dapat diuji bila dua orang/lebih memeriksa secara independen, akan menghasilkan informasi yang sama.

Ciri-ciri tersebut relevan dengan dimensi waktu, isi dan bentuk sebagai cara menilai kualitas informasi, akan tetapi permasalahan yang dihadapi masyarakat berkaitan dengan penyebaran informasi tidaklah sederhana dan hanya cukup dilihat dari sisi materinya. Dampak informasi tidak terbendung akibat penggunaannya yang sarat kepentingan. Tidak jarang masyarakat sulit membedakan informasi yang benar dan informasi yang tidak benar karena keduanya telah bercampuraduk. Dalam hal ini terdapat istilah misinformasi, disinformasi dan malinformasi. Menurut UNESCO di dalam panduan untuk pelatihan jurnalisme $(2018,44)$, misinformasi adalah informasi tidak benar, disebarkan oleh orang yang mempercayainya sebagai hal yang benar. Disinformasi adalah informasi tidak benar, disebarkan oleh orang yang mengetahui ketidakbenarannya. Sedangkan malinformasi adalah informasi berdasarkan kenyataan, tetapi digunakan untuk merugikan orang, organisasi atau negara.

Sementara itu upaya identifikasi karakteristik informasi, menggunakan al-Qur'an sebagai sumber telah dilakukan juga oleh para ahli, beberapa di antaranya (Kahfi 2006) yaitu,

1. Informasi harus dapat meneguhkan hati penerimanya, seperti QS 11: 20,

2. Tidak mencampuradukkan kebenaran dan kebatilan: QS 2: 42 dan tidak menyembunyikan kebenaran QS 2: 146,

3. Dapat menyelesaikan perselisihan: QS 2: 213,

4. Mencegah praduga yang salah: QS 3: 154,

5. Menumbuhkan semangat kompetisi dalam kebaikan: QS 5: 48,

6. Menyentuh perasaan untuk menerima kebenaran: QS 5: 83.

Ambillah kualitas yang kedua, yaitu tidak bercampurnya kebenaran dengan kebatilan dan tidak menyembunyikannya. Berbagai peristiwa menunjukkan bahwa penyebarluasan informasi seringkali tidak mengindahkan kebenaran, baik dilakukan secara sengaja atau tanpa niat merugikan tetapi malas untuk memverifikasi, yang menyebabkan kekacauan informasi. Sebuah narasi berita berpotensi untuk menjadi bentuk disinformasi dan misinformasi, ketika memuat satire/parodi yang membingungkan, membuat hubungan yang salah, memuat konten yang menyesatkan, konteks yang salah, konten tiruan, manipulasi dan konten rekaan (UNESCO 2018, 52). Apabila dilakukan secara sengaja, maka dikatakan telah berbohong. Di dalam kajian psikologi komunikasi terdapat teori kebohongan, yang menerangkan bahwa kebohongan itu merupakan manipulasi disengaja terhadap informasi, perilaku dan gambaran diri dengan maksud mengarahkan orang lain kepada kepercayaan atau kesimpulan yang salah (Morissan 2010, 143). Mengapa orang berbohong? Gregory Hartley dan Maryann Karinch di dalam buku How to Spot a Liar (Hartley dan Karinch 2005, 36-38) menyatakan bahwa manusia berbohong untuk perlindungan diri, karena ingin bersikap sopan, karena rasa benci, dan karena ketamakan untuk keuntungan pribadi. Pandangan teologis terhadap kebohongan, salah satunya dapat diperiksa pada QS an-Nur: 14-15, yang memperingatkan agar tidak menganggap ringan kebohongan. Konsekuensi penyebaran berita yang tidak terverifikasi yang bisa disaksikan sekarang adalah timbulnya chaos atau kekacau-balauan di tengah masyarakat.

Pembahasan topik komunikasi akan berjumpa dengan konsep-konsep yang mengandung nilai keislaman. Dalam konteks ini tabayyun menjadi inspirasi untuk menggali 
kriteria informasi yang berkualitas dari sumber keagamaan yang paling utama. Urgensi tabayyun sangat jelas pada kasus yang menjadi latar belakang turunnya ayat keenam surah al-Hujurat itu dan relevansinya semakin dirasakan di dalam kehidupan modern. Sebagai contoh dalam jurnalisme terdapat prinsip kejujuran, fakta, dan verifikasi (Yuniati dan Rachmiatie 2006). Para jurnalis pembawa pesan terikat kepada kode etik yang mengatur bahwa pemberitaan tidak mengandung kebohongan, hal yang sebenarnya A tidak boleh dikatakan B karena demikianlah faktanya. Tidak ada fakta yang disembunyikan, dan telah melalui proses pemeriksaan terhadap kebenarannya. Mereka adalah penyampai pesan kepada masyarakat melalui komunikasi massa yang audiensnya sangat luas. Media komunikasi berupa surat kabar, majalah, radio dan televisi adalah saluran yang kontennya diarahkan oleh redaksi, dan penyiarannya dapat dikontrol oleh pihak berwenang. Apabila materinya meresahkan masyarakat akan turun peringatan dari komisi yang telah dibentuk oleh pemerintah. Berbeda problemnya bagi media sosial yang dimiliki secara personal. Kontrolnya terletak internal pada diri pemiliknya. Tidak bisa dilakukan kontrol terhadap konten media sosial. Dampak dari hal itu marak bertebaran ujaran kebencian, fitnah, dan berita rekayasa.

Pada sisi ini, penerima pesan dituntut untuk bertabayyun dengan memeriksa sumbersumber, pesan atau informasi yang diterima, dan menguji metodologi pengumpulan dan analisisnya, yang di dalam kegiatan penelitian dimaksudkan dengan strategi validasi (Connaway dan Powell 2010, 232). Pemeriksaan terhadap sumber termasuk melihat siapa yang menyampaikannya. Perlu diperhatikan bahwa ayat keenam dari surah al-Hujurat itu menyebut orang fasiq si penyampai pesan. Ensiklopedia al-Qur'an yang disusun oleh Quraish Shihab dkk (2007, 219-222) menerangkan bahwa penyebutan fasiq berkaitan dengan perbuatan maksiat mencakup dosa besar dan dosa kecil, terlebih yang berbentuk ucapan. Perbuatan fasiq mengancam keutuhan dan tatanan kehidupan masyarakat. Pelakunya tidak hanya orang-orang kafir, tetapi seorang muslim yang padanya melekat sifatsifat jahat bisa mendapat julukan fasiq. Komunikator yang berkarakter fasiq menyampaikan informasi yang mengandung kebohongan. Untuk komunikasi yang efektif, informasi yang disampaikan harus akurat dan berkualitas. Namun orang fasiq tidak mempermasalahkan kualitas informasi meskipun apa yang mereka sampaikan berpotensi merusak hubungan antarpribadi, hubungan di dalam keluarga, organisasi dan masyarakat.

\section{Implikasi Teoretis}

Pembahasan dalam subbagian ini adalah unsur komunikator, komunikan dan pesan. Komunikator dan komunikan bersifat timbal balik, dalam arti manusia sebagai pelaku komunikasi berperan sebagai penyampai sekaligus penerima pesan. Manusia memiliki peralatan jasmaniah dan peralatan rohaniah yang keduanya berperan ketika manusia melakukan komunikasi. Peralatan jasmani manusia adalah organ yang terlihat konkret seperti mata, telinga, tangan dan mulut. Sedangkan peralatan rohani bersifat abstrak tetapi fungsinya dapat dirasakan yaitu akal, budi, naluri dan hati nurani. Pembagian semacam ini dilakukan Vardiansyah dalam membedakan manusia dengan makhluk lainnya $(2004,38)$. Akal berfungsi untuk mengingat, membedakan, menganalisis dan menyimpulkan berdasarkan logika, yaitu jalan pikiran yang masuk akal dan cenderung obyektif. Budi menjalankan fungsi etika untuk membedakan baik dan buruk, estetika ketika menilai keindahan, dan etiket untuk menilai kesopanan, serta perasaan keadilan dalam menilai adil dan tidak adil. Naluri, yang disebut juga dengan insting adalah bawaan manusia sejak lahir untuk berperilaku tertentu guna keberlangsungan hidupnya. Manusia memiliki naluri ketuhanan, naluri bersosial, naluri ingin tahu dan naluri untuk berkomunikasi. Selanjutnya menurut Vardiansyah, hati nurani adalah pembimbing manusia di saat akal, budi dan naluri tidak bisa memberi keputusan dan ia berada dalam kebimbangan (2004, 39-46). 
Kemampuan perangkat jasmaniah dan rohaniah berkembang dan dipengaruhi oleh usia, pendidikan, pengalaman dan lingkungan manusia. Karena itu setiap orang berbeda sikap dan tindakannya di saat menghadapi persoalan hidup.

Surah al-Hujurat: 6 melekatkan karakter manusia pelaku komunikasi dengan keimanan dan kefasiqan. Ciri-ciri keimanan bisa ditelusuri misalnya di dalam surah al-Mu'minun:1-9, yaitu salat dengan khusyuk, menjauhkan diri dari perkataan dan perbuatan tidak berguna, membayar zakat, memelihara kemaluan, menunaikan amanah dan janji, dan memelihara salat. Menurut Yusuf, terdapat 880 ayat al-Qur'an yang mengandung kata-kata dari akar kata $a-m-n$, sedangkan yang menyangkut terma iman dan makna ragam derivatifnya ditemukan sebanyak $45 \mathrm{kali}$, sementara di dalam hadis tersebar 70 tema tentang iman. Iman tidak terbatas pada masalah kepercayaan, melainkan terkait dengan aspek sosial kemasyarakatan (Yusuf 2008). Surat al-Hujurat sendiri sarat dengan tuntunan akhlak, penghormatan kepada Nabi saw. dan umatnya (Fahimah 2014). Etika berkomunikasi dimunculkan dalam ayat keenam, dan di sinilah pelaku komunikasi juga tidak terlepas dari karakter fasiq. Berbagai kata jadian dari fasiq muncul 54 kali di dalam al-Qur'an. Perbuatan fasiq di antaranya mencaci maki, mengejek orang-orang beriman dan memanggil dengan panggilan jelek (Shihab dkk. 2007, 219-222). Sementara dalam berkomunikasi mereka menyampaikan berita bohong.

Unsur berikutnya yang perlu dibahas adalah pesan dalam komunikasi, yang maksudnya berupa seperangkat simbol verbal dan nonverbal, mewakili perasaan, nilai, gagasan atau maksud dari pengirim pesan (Mulyana 2012, 70). Pada ayat tentang tabayyun disebut dengan naba' yang berarti pesan, berita yang berpengaruh luas terhadap masyarakat. Indeks ayat-ayat al-Qur'an susunan Ilmi Zadah Faidhullah al-Husni mendaftar ada 15 kata naba' (dan an-naba') ditambah 12 bentukan katanya (al-Husni, t.t.). Dari segi kekuatan pesan terdapat istilah naba' dan khabar. Menurut Hefni, naba' adalah pesan yang mempunyai pengaruh luas, apakah pesan itu salah atau benar. Sementara khabar adalah pesan yang pengaruhnya biasa saja. Selanjutnya Hefni mengemukakan sejumlah contoh ayat yang mengandung kata naba' yaitu QS 6:34 dan 67, QS 79:2, QS 27: 22 dan 27, QS 28:3, dan QS 49:6 (Hefni 2015, 111-115). Semuanya merupakan pesan yang membawa dampak besar bagi kehidupan umat manusia sehingga digunakanlah kata naba' oleh al-Qur'an.

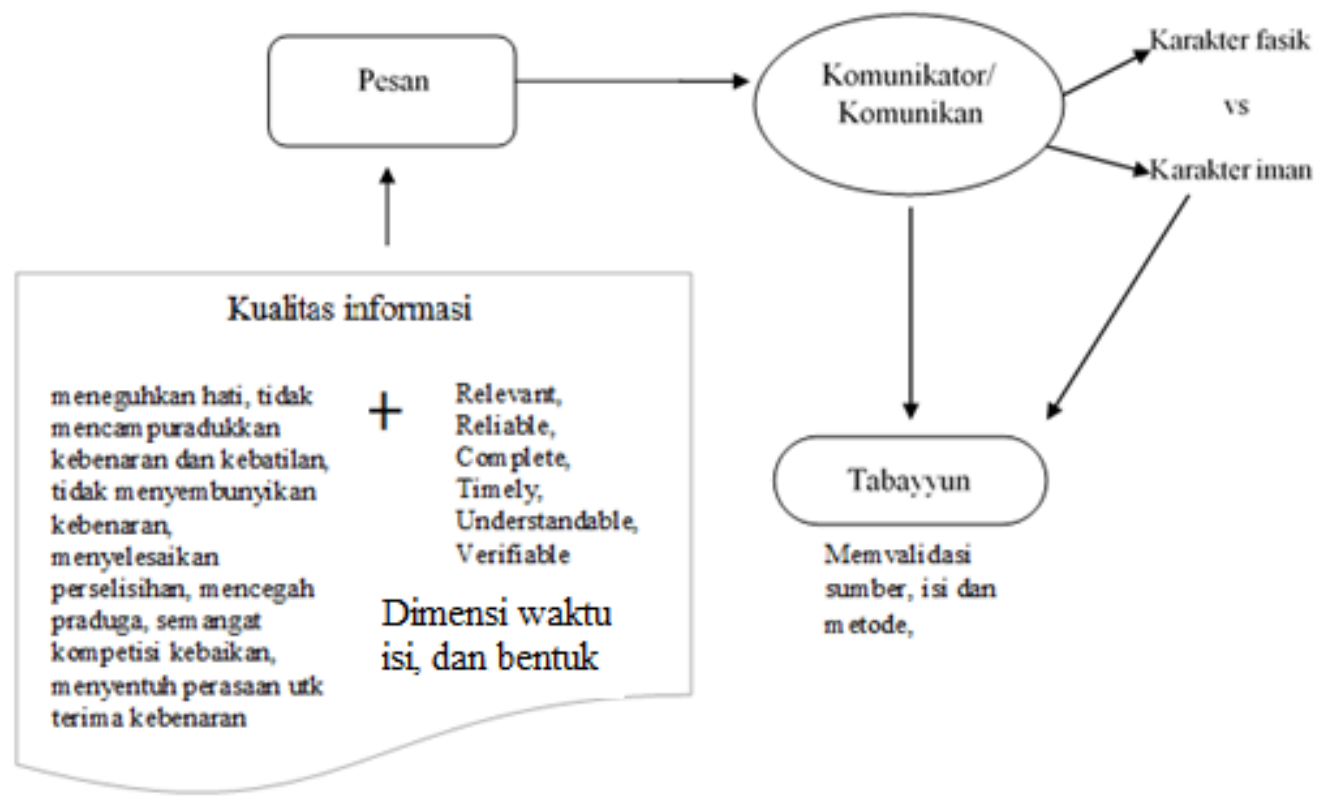

Gambar 2. Model teoritis komunikasi dengan tabayyun 
Dari uraian di atas, penulis mencoba memadukan secara teoritis hasil kajian konvensional para ahli komunikasi dengan kajian yang mengambil sumber dari agama Islam. Dimulai dengan menunjukkan model komunikasi yang bertolak dari model sederhana seperti gambar 1, model pada gambar 2 kemudian memasukkan konsep tabayyun ketika menghubungkan komunikator/komunikan dengan pesan. Keimanan menjadi landasan berkomunikasi dengan tujuan menyebarkan kedamaian dan keselamatan di tengah masyarakat. Kondisi itu diupayakan melalui pesan-pesan yang berkualitas dari sisi materi dan metodologinya, mengandung muatan dakwah baik dengan target personal maupun kelompok yang ada di sekitarnya. Sikap tabayyun merupakan tuntunan etika ketika dalam komunikasi mendapati sumber bahkan audiens yang memiliki karakter buruk sehingga dapat mengeliminasi kesalahan dalam menyikapi suatu persoalan.

\section{E. KESIMPULAN}

Memposisikan tabayyun yang berasal dari perbendaharaan terminologi keagamaan ke dalam bidang komunikasi adalah suatu upaya yang mungkin dilakukan tanpa menunjukkan superioritas atau subordinasi melainkan saling melengkapi. Tabayyun sangat urgen di dalam komunikasi terlebih lagi masyarakat saat ini mengalami keterbukaan dan kemudahan dalam menyampaikan informasi. Karena itu diperlukan tabayyun sebagai sikap untuk memperhatikan kualitas informasi yang diterima dan yang disampaikan. Dampaknya, diharapkan komunikasi terbangun secara efektif sekaligus memiliki landasan teologis. Tulisan ini memiliki banyak keterbatasan, maka teoritesasi yang penulis bangun di dalamnya perlu dicermati dan dilengkapi melalui penelitian dan refleksi lebih mendalam, sehingga upaya dimaksud menjadi lebih komprehensif.

\section{DAFTAR PUSTAKA}

Arifin. 2018. "Kajian Komunikasi Massa Pada Surah Al-Hujurat Ayat.” Jurnal Ilmiah Mahasiswa Raushan Fikr 7 (1): 35-50. https://doi.org/10.24090/jimrf.v7i1.2205.

Azemi, Nor Athirah, Hazlifah Zaidi, dan Norhayati Hussin. 2018. "Information Quality in Organization for Better Decision-Making." International Journal of Academic Research in Business and Social Sciences 7 (12): Pages 429-437. https://doi.org/10.6007/IJARBSS/v7-i12/3624.

Connaway, Lynn Silipigni, dan Ronald R. Powell. 2010. Basic Research Methods for Librarians, Fifth Edition. California: Libraries Unlimited.

Dahlan, A.A., dan dkk. 2000. Asbabun Nuzul Latar Belakang Historis Turunnya Ayat-Ayat al-Qur'an. Edisi kedua. Bandung: Diponegoro.

Dawson, Catherine. 2002. Practical Research Methods: A User-Friendly Guide to Mastering Research Techniques and Projects. Oxford: How to Book, 2002, hal. 115. Oxford: How To Books.

Efendi, Erwan. 2016. "Tabayyun dalam jurnalistik.” Komunika Islamika: Jurnal Ilmu Komunikasi dan Kajian $\quad$ Islam 3 (3). http://www.jurnal.uinsu.ac.id/index.php/komunika/article/viewFile/1845/1477.

Fahimah, Siti. 2014. "Etika Komunikasi Dalam Al-Quran: Studi Tafsir Surat Al-Hujurat Ayat 1 - 8." Madinah: Jurnal Studi Islam 1 (2): 95 - 108-95 - 108. https://ejournal.iai-tabah.ac.id/index.php/madinah/article/view/153. 
Ghazali, Masitah dkk. 2017. "To Share or Not to Share: Tabayyun Made Possible with MyVeri5." Advanced Science Letters $23 \quad$ (5): 4542-45. https://doi.org/10.1166/asl.2017.8981.

Gorla, Narasimhaiah, Toni M. Somers, dan Betty Wong. 2010. "Organizational Impact of System Quality, Information Quality, and Service Quality.” The Journal of Strategic Information Systems 19 (3): 207-28. https://doi.org/10.1016/j.jsis.2010.05.001.

Hanafi, Hanafi. 2017. "Multikulturalisme Dalam Al-Qur'an, Hadits Dan, Piagam Madina." SAINTIFIKA ISLAMICA: Jurnal Kajian Keislaman 3 (02): 169-90. http://jurnal.uinbanten.ac.id/index.php/saintifikaislamica/article/view/97.

Hartley, Gregory, dan Maryann Karinch. 2005. How to Spot a Liar: Why People Don't Tell the Truth-- and How You Can Catch Them. Career Press.

Hefni, Harjani. 2015. Komunikasi Islam. Jakarta: Kencana.

Humdiana, dan Evi Indrayani. 2006. Sistem Informasi Manajemen. Kedua. Yogyakarta: Graha Ilmu.

al-Husni, Ilmi Zadah Faidhullah. t.t. Fathurrahman li Thalibi Ayatil-Qur'an. Indonesia: Makatabah Dahlan.

Kahfi, Agus Sofyandi. 2006. "Informasi dalam Perspektif Islam." Mediator: Jurnal Komunikasi 7 (2): 321-328. https://doi.org/10.29313/mediator.v7i2.1274.

Kamus Online Almaany. 2019. تعريف و معنى تبين في معجم المعاني الجامع - معجم عربي عربي. 2019. https://www.almaany.com/ar/dict/ar-ar/ تبين.

Kenett, Ron S, dan Silvia Salini. 2011. "Modern Analysis of Customer Satisfaction Surveys: comparison of models and integrated analysis." Applied Stochastic Models in Business and Industry 27 (5): 465-75. https://doi.org/10.1002/asmb.927.

Marang-van de Mheen, P. J., J. Dijs-Elsinga, W. Otten, M. Versluijs, H. J. Smeets, R. Vree, W. J. van der Made, dan J. Kievit. 2011. "The Relative Importance of Quality of Care Information When Choosing a Hospital for Surgical Treatment: A Hospital Choice Experiment." Medical Decision Making 31 (6): 816-27. https://doi.org/10.1177/0272989X10386799.

Morissan. 2010. Psikologi Komunikasi. Bogor: Ghalia Indonesia.

Mulyana, Deddy. 2012. Ilmu Komunikasi: Suatu Pengantar. Bandung: Remaja Rosdakarya.

Noor, Muhammad Usman. 2018. "Penilaian Kualitas Informasi Sebagai Bentuk Sikap Tabayyun Ketika Menerima Informasi di Sosial Media dan Internet." BIBLIOTIKA 2 (1): 33-40. https://doi.org/10.17977/um008v2i12018p033.

Shihab, Quraish dkk. 2007. Ensiklopedi AL-Qur'an Kajian Kosakata. Jakarta: Lentera Hati.

Soyomukti, Nurani. 2016. Pengantar Ilmu Komunikasi. Yogyakarta: Ar-Ruzz Media.

al-Thabari, Abu Ja'far Muhammad bin Jarir. Terj. Abd. Somad dan Abdurrahim Supandi. 2009. Jami'ul bayan 'an Ta'wil Ayil Qur'an. Jil. 23. Jakarta: Pustaka Azzam.

UNESCO. 2018. Journalism, 'Fake News' \& Disinformation: Handbook for Journalism Education and Training. France: UNESCO. http://unesdoc.unesco.org/images/0026/002655/265552E.pdf.

Vardiansyah, Dani. 2004. Pengantar Ilmu Komunikasi: Pendekatan Taksonomi Konseptual. Jakarta: Ghalia Indonesia. 
Widarsono, Agus. 2007. "Pengaruh Kualitas Informasi Manajemen Terhadap Kinerja Manajerial (Survey pada perusahaan go-publik di Jawa Barat)." Jurnal Akuntansi FE Unsil 2 (2): 286-99.

Yuniati, Yenni, dan Atie Rachmiatie. 2006. "Komitmen Wartawan Terhadap Jurnalistik Publik." MIMBAR 22 (1): 53-92. https://doi.org/10.29313/mimbar.v22i1.201.

Yusuf, Muhammad. 2008. "Nilai-Nilai Sosial-Humanistik dalam Teks Hadis (Konstektualisasi Makna Iman Secara Integratif-Interkonektif)." Jurnal Penelitian Agama XVII (3): 477-96.

Zed, Mestika. 2004. Metode Penelitian Kepustakaan. Jakarta: Yayasan Obor Indonesia. 